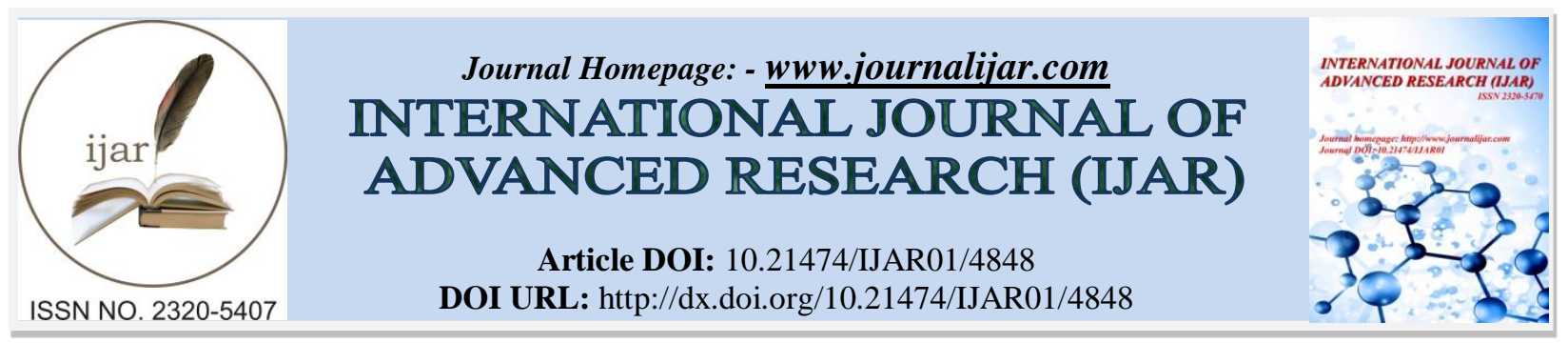

RESEARCH ARTICLE

\title{
THE ROOTS OF THE PERIPHERY: A HISTORY OF THE GONDS OF DECCAN INDIA. NEW DELHI: OXFORD UNIVERSITY PRESS, 2017, PP. XVII+ 209, RS. 750.
}

Sujata Sahoo.

Ph.D. Scholar University of Hyderabad.

\section{Manuscript Info \\ Manuscript History \\ Received: 14 May 2017 \\ Final Accepted: 16 June 2017 \\ Published: July 2017}

Abstract

On $18^{\text {th }}$ January, 2017, an analytical discussion of the book "The Roots of the Periphery: A History of the Gonds of Deccan India" was fascinate me to assume the pivotal theme of Adivasi studies in general and the debate on Gond community in particular. The prominent anthropologists and activities like Prof. Kalpana Kannabiran, Prof. Kancha Ilaiah and Prof. Susie Tharu stated very critically the pros and cons of this work of Dr. Bhangya Bhukya, i.e. the pathway from his former work Subjugation of Lambardas to the Root of the Periphery, the attempts and activities to degrade the status of Gond community of Chanda and Adilabad region under the Mughals, Marathas, Nizams, the colonial rulers as well as the independent Indian government. The book under review The Roots of the Periphery is of the conclusion that exhibit the uprooting of the solemn culture of the Gond adivasis due to the interference of different non-adivasi forces. This pamphlet illustrates the political formulation of the periphery, the straight cut civilization and complex relationship between the mainland and highland territories. The accounts of the Andre Beteille and Nandini Sunder on the problematic formation of class, caste and tribe as well as the British colonial state effects in the hills and forest dwellers of India respectively are given the brief. The introduction clearly romanticizes the ecological disturbances due to the stipulation on shifting cultivation, the identification and interpretation of adivasis and their socio-cultural status. Similarly the statement of Archana Prasad was also argued against the description of adivasis as backward Hindus, barbarians and primitive for the state making process by Verrier Elwin, James C. Scott and G. S. Ghurey.

The author depicts the gradual evolution of the periphery under the state making process and by the Brahmanic and the non-Brahmanic Hindu texts. From the very Ancient period, the tradition of warfare among big empires, the land grants, evasion of land tax as well as forceful caste practices led them to shift from plain to the rugged land. Addition to that the feudal system was emerged with the emergence of Kakatiyas, Vijayanagara and Qutabshahi Kingdoms in south India as the offshoot of the extension of area under cultivation and increasing cash crop cultivation. Revenue concessions, new formation of villages in forest and waste lands, tank irrigation and religious based discriminations (P. 9) provided boost for the expansion of the plain land high caste people like Kumbis of Berrar, Kapu (Reddy) and Velama from Krimnagar and Warangal, Kammas from Andhra region in Chanda district towards forest. The migration unconsciously laid a smooth assimilation process between the plain land and the periphery. But the subsistence of the Gonds, their land and forest became commercialized by the British sovereignty, which discards the traditional rights of the head of the groups under Maratha and Nizam rule. 
Now author demarcates different phases of the periphery under different sovereigns. How it changes from a political zone to a socio-cultural zone under the colonial government is elaborated and analyzed. The author also emphasizes the biasness in the construction of the history of Gond community by the colonial anthropologists and academicians. As because the using of the oral sources were valorized, so the real glory of the community was exaggerated. But the British anthropologists and the administrators constructed the stories of the community on the archival and archeological evidences too. Ain-I-Akabari was the earliest record which mentioned Babaji Ballal Shah (one Gond King) in Sirpur. C. B. Luice Smith was placed the character of Balal Shah as the organizer of the Gond tribes in 870 C. E. and gives the chronology of nineteen Gond rulers. The second chapter gives the details of the ethnographic and genealogical past of the Gond adivasis. The Gond mythical stories denote their Dravidian origin. Hiuen-t-sang, the Chinese pilgrim traced the Buddhist influence in the Gondwana region during Satavahana rule down to seventh and eighth centuries C.E. This piece includes the territorial boundaries and the four indigenous groups of the Gonds, i.e. the Raj Gonds, the Maria or Madia Gonds, the Dhurve Gonds and the Khatulwar Gonds addind several minor subadivasi groups. General Alexander Cunningham, R. V. Russel and Furer Haimendorf extensively ascertained their origin from different races of India. Dr. Bhukya discussed the socio-cultural ethics of the community from Dr. Birshah Atram, causin of Yadav Shah, the Raja of Gondwana region. Mr. Atram describes the recent poor economic condition and the drained power of the Gaddi (royal throne), that he is not able to practice the traditional Dussehara celebration.

\section{Enclosing Gond Sovereignty, entity, Forest and land:-}

The three successive major chapters contain the enclosing adivasis, forest and land. With the advent of the Britishers, the forest administrators diplomatically subordinated the rugged land and the community rulers by showing the paternalistic attitude towards them, to which Nicholas Dirks called it as "hallow crowns" (Rajas with very limited power). Still from 1798-1817, the Gond Rajas and the chiefs rebelled against the expansion of the colonial hegemony over the agricultural crops and land revenues. The Chanda territory, the then capital city of Gondwana kingdom fell into the British yoke on $2^{\text {nd }}$ May 1818, but the secret guerilla warfare continued by Babu Rao, a Gond Raja of Mallampalli and Venkat Rao, Gond zamindar of Arapalli and Ghat. But the rebelled were suppressed, crushed and punished ruthlessly. It shows the tyranny of the colonial administrators over the forest resides. Except this the growth of education, the process of westernization, Hinduization and Rajputaization were vibrant. The rise of intellectual class gave rise to a self-conscious group and they turned against the colonial exploitation, the remove of the title of Raja and reduction of the power of the Zamindars.

British enclosed land and forest subordinated and marginalized the hill and forest dwellers, commercialized agriculture to develop market based economy, implemented new forest laws, constructed railways, gave waste and forest land for cultivation to the caste- Hindu peasants under Ijara system. Moreover, the new forest regulations also demarcated the whole adivasi land into conserver forest and waste forest areas. The civilizing agricultural mission was also benefited by the river valleys like Inderaveli, Mahanadi and many minor streams. The red or sandy soil and the black soil of the north-west belt favored the rice cultivation and plough cultivation adding to the Dhaya/ Podu Chasa (Shifting cultivation). So the Gond region was no more a free zone which led to the enclosement of adivasi culture. The Pattas on land rights was not recorded before, so that the colonial state easily grabbed the territory as well as the forest produce such as grass, Mahua, Chironji (berries) and Bamboo in the Gond region. The heavy famines of 1895-97 and 1899-1900 made a heavy loss of the man resources. The famine reports recorded heavy migration of the Gonds to other regions which gave space to the plain land community to intrude into that region. Poorly implemented Land Alienation Act of 1916 was revised by the Act of 1935 under the partially Excluded areas clause. So, Dr. Bhukya coated Archana Prasad's "Ecological Romanticism" to emphasize the term "protectionism" in forest by the celebrated tribal masculinity meant by colonial administrators and forest officers. This notion was also extracted from the plain land culture. In the beginning of the $20^{\text {th }}$ century, the Gonds also adopted and adapted the Brahmanical practices and worshipped Hindu Gods.

\section{Resistance against Colonial Autonomy:-}

Resistance is a part of civilization making process. The Kumaram Bhimu's revolt in Adilabad district against the Hyderabad state in 1940s was more prominent. But there are no literary and written evidences. The author also enabled how the Cambridge, nationalist and Marxist schools also failed to understand the depth of the adivasi resentments. So they make distinctions between the adivasi insurgency and hegemonic nationalist movement. The nature and approach of the schools towards the adivasi resurgences were exposed by Alpa Shah and she commented on the neutrality of Ranjit Guha towards the destructive role of the Church in the collaboration with the colonial 
state. Instead of the absence of the literary sources, Haimendorf collected the oral sources and depicted how the continuous harassment and evictions by forest and land revenue officers led the Gond towards the insurgency by Kumaram Bhimu in Jodeghat. The official records also informed misleading records, so the Andhra Mahasabha appointed a fact finding committee consisting of B. Yelle Reddy, Narasingha Rao, B. ramkishen Rao and Ravi Narayan Reddy. Haimendorf mention how different religious and political groups raise voice against the Muslim administrators in that region like the local Komatis and Marwaris. For Example, the support of Arya Samaj was religious intensity whereas the Hindu Prajamandal was of political intensity. Moreover the influence of the Christian Missionaries and the Rashtriya Swayamsevak Sangha from the Marathawada region was very harmful in this incident. But their demand was to get rid of Dumpa patti (plough tax) and grazing fees rather than political freedom, was stated by Haimendorf. But he failed to interpret the notion of political autonomy for the Gond community as per the State Reorganization Commission of 1950s.

Anthropological development resulted the formation of All India Tribal Welfare Bureau, constituted of both administrators and anthropologists. Haimendorf and Grigson also described drunkness, large quantities of homebrewed liquor for festivals, marriages and worship, which was a major cause of their underdevelopment. Author also depict here, the life and ideologies of Haimendorf, like Gond education, administrative reforms, reforms in revenue assessment, train them to function within the forest and revenue department, land distribution, rehabilitation planning, establishment of the public health department. Here Dr. Bhukya also commented on the Nehru's Panchasheela Principle (tribal policy in India) was influenced by Elwin's Ecological Romanticism.

With the conclusive remark, the author tells about how under the independent government, the adivasi society was changed from participatory democracy to representative democracy. The resurgence is continued till now and the anthropological development gave space to raise voice again against the unrest in 1981. On $20^{\text {th }}$ April of the same year Girijana Rythu Coolie Sangam (Tribal Farmers and Labourers Union) of Adilabad district organized protest meeting against the mass butchering in the Indraveli incident. The author stated the relevance of the study of mainland and hill periphery history simultaneously, because without the concern of both, the social history writing is quite impossible.

\section{References:-}

1. Arnold, David, and Ramachandra Guha, eds. Nature, Culture, Imperialism: Essays on the Environmental History of South Asia. New Delhi: Oxford University Press, 1955.

2. Beteille, Andre. Caste, Class and Power: Changing Patterns of Stratification in a Tanjore Village. New Delhi: Oxford University Press, 1971.

3. Bhukya, Bhangya. Subjugated Nomads: The Lambardas under the Rule of the Nizams. New Delhi: Orient Blackswan, 2010.

4. Dirks, Nicholas B. Caste and Mind: Colonialism and the Making of the Modern India. New Delhi: Permanent Black, 2002.

5. Pati, Biswamoy, Adivasis in Colonial India: Survival, Resistance and Negotiation. Edi. New Delhi: Orient Blackswan, 2011.

6. Prasad, Archana. Against Ecological Romanticism: Verrier Elwin and the Making of an Anti-Modern Tribal Identity. New Delhi: Three Essays Collective, 2003.

7. Rangarajan, Mahesh. Fencing the Forest: Conservative and Ecological Change in India's Central Provinces 1860-1914. New Delhi: Oxford University Press, 1996.

8. Von Furer-Haimendorf, Christoph. Life among Indian Tribes: The Autobiography of an Anthropologist. New Delhi: Oxford University Press, 1990. 